\title{
Shaping Tourist Destinations Through Language and Visual Elements on Tourism Websites: A Tourism Discourse Perspective
}

\author{
Muhammad Arfin Muhammad Salim ${ }^{1}$, Ahmad Puad Mat Som* \\ ${ }^{1}$ Politeknik Pariwisata Makassar, Kota Mandiri Tanjung Bunga, Kota Makassar, Sulawesi Selatan, Indonesia \\ ${ }^{2}$ Faculty of Applied Social Sciences, Universiti Sultan Zainal Abidin, Gong Badak Campus, 21300 Kuala Nerus, Terengganu, Malaysia \\ *Corresponding authorE-mail: puadms@unisza.edu.my
}

\begin{abstract}
Official tourism website has become an essential aspect in shaping tourist destinations. Tourism websites are an essential tool in shaping the norms and values of the destinations which travelers have to visit - however, only very few research which focused on the integration of the language element and visual element in shaping tourist destination images. Thus, this study aims to investigate how effective is the use of language and visual elements in shaping the tourist destination on the tourism websites of Sulawesi Selatan, Indonesia. This research employed a discourse approach to analyze both language and visual elements. Data was collected via online documentation and semi-structured interview and analyzed using both textual and visual analysis. The use of lexical and syntactical aspects in the official tourism websites in Sulawesi Selatan, Indonesia are the focus of textual analysis. Furthermore, visual elements such as modality and salience are also looked over. The findings reveal that both, textual and visual elements, complement each other as tourism discourse resources, in realizing Indonesia's tourism destinations as attractions on official tourism websites (OTWs).
\end{abstract}

Keywords: Language of Tourism; Tourism Discourse; Website; Promotion; Destination.

\section{Introduction}

In tandem with the national growth of revenue in most countries, the major turn down of the cross-border movements of liberalization, the costs of transportation, and the growing propensity to travel around the world, the total international tourist arrivals in as a whole remains to increase. Thus, most regions including Indonesia have worked to increase and develop tourist arrivals. The tourism investment has significantly increased [1]. Tourism promotional activities have positively impacted to shape and portray the tourism destination. Indeed, the element of language use and visual are the aspects which generate specific discourse [2-5]. Some research investigated tourism discourse by focusing on examining the role of language usage or visual element separately [6]. Conversely, only a few if any which focuses on examining the integration text and visual element on tourism websites (OTWs) [7-9]. Language use and visual element are part of discourses which play an essential part to shape the destination [2]. Hence, this study focuses on investigating language or texts, and visual elements work together to digitally shape the destination on the tourism website of South Sulawesi. Tourism has become a vital sector of Indonesia's economic development including South Sulawesi region. This region has much to offer, from the historical and cultural attraction. In 2015, South Sulawesi recorded 400,380 tourist arrivals. This number shows that South Sulawesi is one of the favorite destinations in Indonesia. However, this number does not lift the position of South Sulawesi in the top ten destinations in Indonesia.

Nature and cultural heritage are the vital assets of tourism in South Sulawesi. They claim them as unique combination of the attractions. As a popular destination, South Sulawesi has many different ideal tourism assets. These natural temptations are completed by a ludicrous cultural heritage that reveals South Sulawesi's dynamic culture and tradition. Given that online promotional media has a significant role to enhance the destination value, the website and other printed media have become a principal tool to market and promote the destination [2, 10, 11]. Therefore, this current study focuses on researching how language and visual elements shape the tourism destinations in South Sulawesi, Indonesia on the government tourism website.

Online tourism promotion is an essential initial tool to develop the tourism stakeholders' communication to potential tourists. Tourism promotional tool consists of two categories: printedbased promotion (e.g., brochure, booklet, and leaflet) [6] and online-based promotion (e.g., website, and social media) [7, 8]. The online-based promotion has become a favorite tool to promote the destination in the industrial 4.0 era. It also claimed as the more reachable in this era. The language and visual elements are the dominant strategies used to portray the destination [12-15]. The integration between visual and text elements create specific discourses to shape the destinations. Indeed, text [16] and visual image $[17,18]$ are the essential aspects of shaping the tourism discourses on OTWs. Through the discourse of tourism, tourist destination branding image can be established to boost the destination portrayal. However, there are a few studies which focus on examining the use of language use and visual aspects to shape the tourist destination on tourism websites [7]. Moreover, $[19,8]$ suggest the use of language and integrated visual to explore data sources and social semiotics. Therefore, the focus of this research is to investigate the role of language and visual aspects to convey tourist destination websites of South Sulawesi. 


\subsection{The Concept of Tourism}

Tourism comprehensively is reflected as a recreational activity which is boosting societies to conduct a physical movement to destinations for a certain period with an intention to return home. As a world industry, tourism consists of a mixture of activities, services, and attractions which can be enjoyed by everyone [20] The tourism industry also represents the countries' identity and culture [21]. In [21] further argues that through the images of tourism, the tourist can recognize and meet the local culture and tradition. Although local people may have abandoned the tradition itself, the tourism industry can contribute to sustaining it. Therefore, the national identity can be seen from their culture and thus become like an object of tourism.

In an academic environment, tourism covers an idea of relationship and phenomena occurring out of the journeys and temporary stays of trips taken for leisure and recreation [22]. Hence, tourism comprises the ideas and opinion people hold which shape their decision of going on a trip, what to see, where to go, what to do and not to do and how to connect tourism with others. Sociologically, the tourist relationship takes place from peoples' movement to and their stay in different destinations [23, 24].

\subsection{The Language of Tourism}

The language of tourism is universal and accustomed in society; subsequently, a persuasive strategy is used by the media and invented in conversation to convey the universality. The use of language manipulates the reality and the secret of the destination. Hence, language is the most influential driving force to introduce the tourism destination [25].

As a discourse, tourism has become one of the main concerns to the many discourse community, with many people involved in its construction when entering the many numbers of the communicative situation [26]. From a promotional perspective, tourism is specialist and patron that has its discourse [27]. Realized to this light, the language of tourism is more than a symbol. The language of tourism likely persuades and seduces people to be from potential to real tourists through motionless, text and moving pictures [16].

Language and visual aspects naturally represent and reflect the reality of the world $[28,5]$. Tourism websites ideally discover language and visual aspects to offer potential tourists and change the tourist's understanding and perception of the products and destinations. Therefore, the interrelation between text and image may represent and portray the tourist attractions and products on the tourism website.

Some research has been carried out in term of the tourism promotional media, from online to the printed media [29-31]. However, few researchers have explicitly addressed the role of language and visual image in these promotional platforms in valorizing the destination $[32,7]$. These studies focus mainly on the content which appears on the tourism websites, often overlooking an essential aspect of the discourses of the tourism promotion. Truthfully, language and visual are the aspects which create particular discourses, to shape the image and identity of destinations [3, 5]. Indeed, tourism websites use both language and visual image to enhance the tourist destination [33, 34]. Consequently, the need for advanced research has become essential in the industrial 4.0 era. Hence, this current study investigates the role of language and visual aspect to shape the tourist destinations

\subsection{The Discourse of Tourism}

Language age and tourism have been paid attention by some scholars such as [35-37] who argue that tourism development depends on how language is used to create the tourist experience toward the destination. Indeed, as [38, 39] discovered it is not that so many destinations are integrally touristic but rather the language used created them to be so. This notion was then developed by [16] who further categorized the role of language use in tourism promotion to contextualize the tourist' experience. As tourism discourse, the study sets language communication into a frame of study and describes tourism as a dominant aspect of the current social life [18, 40-41]. Despite differences in emphasis, discourse is an essential concept in understanding society responses to it, as well as of understanding the language itself [42]. Therefore, tourism discourse plays an essential role in tourism promotion to shape destination image.

\subsection{Tourism Website as Promotional Media}

The website is the most popular tool employed by tourists to discover tourism destinations of the country. Tourists prefer to use online media to get more information about tourist attraction [43, 11]. A result from [44] shows the use of online media to get information about a destination in Indonesia reached $24 \%$ and only $8 \%$ to $15 \%$ use printed. Hence, the website as one of the online media become popular media used by the people to get valuable information of the destination. The development of information technology promotes the use of the online media, for examples, website, social media tend to grow compared with printed media such as booklet, brochure, and other promotional media.

In the tourism industry, an image has a significant role to enhance the tourist destination [45-47]. Hence, the essential factors that can influence tourist arrival are how the promotional mediation portray and valorize the destination. Tourism promotional material covers essential information in which language and visual images are employed, presented and created the destination image. Thus, the role of language use and visual images is to shape the tourist destination - for instance, the use of lexical and syntactical as discourse strategy that can enhance and valorize the destination [5, 48].

The different discourse reflects the effectiveness of the function of websites in enhancing tourist products [11]. Furthermore, many researchers claim that tourism websites effectively provide information that is measured from design, quality, the text used and images. [49-51] found that tourism website conjures a favorable first impression toward the current destination. Therefore, tourism websites are considerably constructing interactions with prospective tourists [52]. Hence, tourism websites have a significant role in providing information as well as maintaining the relationship with current tourists. Language and visual elements play an essential role to valorize the destination through the different discourses of tourism.

Tourism websites have specific structures which differ from the printed promotional mode. The website employs high quality and simple text $[49,53,18]$. Unlike other non-government tourism websites, official tourism website maintains the national identity via different discourses $[54,55]$. Therefore, the official tourism website represents the nation in which language and visual image may have a varied role to portray and valorize the tourist destination.

Furthermore, studies from scholars have explored the quality of the website, taking into account the design, content, visualization, and language in use $[56,57,12]$. Language use and visual images used on official tourism websites assist in increasing the users' satisfaction [41]. Website content and design are also essential features in portraying and enhancing the destination [57].

\section{Methodology}

The qualitative approach is employed in this study to develop a research design. In the tourism research context, this research aims to explore the role of language and visual elements on the tourism websites in South Sulawesi Regencies. The websites are the 
primary data resources and field documentation as the single primary data collection method. Clearly said that for a better understanding of how official websites in South Sulawesi Regencies digitally portray the tourism destination and to ensure constancy of the data collected.

This study employs discourse analysis to analyze the data to attain a better understanding of the role of language and visual elements in shaping enhance the tourist destination $[16,17]$. This analysis is valuable for the study to describe a social phenomenon in general and to make use of inductive simplifying from social reality to a more inclusive theory $[58,59]$. Therefore, this study used two types of analysis, which are visual and textual analysis. The textual analysis focused on analyzing the text found in the tourism websites while visual analysis is utilized examining the visual components of the tourism websites in South Sulawesi.

Data of the research consisted of two categories namely the primary and supplementary data. The primary data contributed to the textual analysis and visual analysis whereas the supplementary data supported the contextual views of the existing text on tourism websites. The former referred to words, phrases, and clauses taken from the text and the visual images in the favorite links and homepages of the Official Tourism Websites (OTWs), namely Makassar, Parepare, Tana Toraja. Furthermore, three areas Makassar, Prepare, Tana Toraja were the locations of the data collection. The data collection was carried out in this study through documentation and interview.

The documentation selected for this study was the tourism websites in South Sulawesi. This primary data collection was carried out through identifying webpages and links, downloading and documenting sources. Moreover, the interview data also provided evidence of the various discourses of OTWs. The study uses criteria in selecting the participants for the interview consisting of local and international tourists. The participants were selected based on three essential criteria, from those who used websites or online search engines to browse and explore before deciding to travel to a destination. Secondly, the informants of the study were the tourists who were visiting the three popular destinations in South Sulawesi: Makassar, Parepare, and Tana Toraja.

In selecting the participants, the researcher visited the tourist spots to meet the participants who were willing to be interviewed. The interview took place about $30-45$ minutes for each participant. The ten questions addressed were about discourses of tourism in both Indonesian and English versions.

\section{Discussion}

This part presents the analysis of tourism websites in South Sulawesi. The purpose of this part is to deliberate on how text and visual elements develop tourism discourse and valorize the tourist attractions on the official tourism websites in South Sulawesi. In modern literature, the language of tourism is a specific type of language which realizes different functions in the specific situation of tourism [16, 7]. As discussed in the theoretical framework which underpinned the study, the use of specific language in tourism websites plays a significant role to construct the reality in a specific situation [58]. The textual data shows that descriptive sentences and descriptive verbs are employed to construct the portrayal of the attractions on tourism websites. Thus far, the discussion of the research focused on the data analysis. Theories, concepts and the related study was integrated to perform the findings. The theoretical framework give emphasis on socia constructionism which is concerned with the how language and visual image construct social activities [58]. Accordingly, discourse constructs all social activities including tourism socially. Cultural heritage, nature, and human-made or play create tourism $[16,60,61,7]$. Thus far, the findings show that the textual and visual image used on three websites work together to construct a discourse of persuasive to allure the potential tourist. For example, it shows that the tourism website of Makassar employed persuasive sentence to persuade the tourist. For example, extract 1 employs persuasive discourse

\subsection{Extract 1}

Salah satu tempat yang menarik yang dapat anda kunjungi di Makassar adalah Benteng Somba Opu (TWM-D, 2017)

The use of personal pronoun Anda (you) in the sentence means that the tourism website engages directly to the tourist to enjoy the tourist attractions. This sentence explains that Makassar has a historical attraction which is exciting to be visited by the tourist, such as Fort Rotterdam, Gowa Kingdom historical buildings and Lagaligo Museum. The tourism website of Makassar uses specific discourse to portray the tourist attraction [11]. However, the website only uses Bahasa to introduce the tourist attraction. The website does not use international language for example English to persuade the potential international tourist. An interview data with one visitor commented that the tourism website of Makassar was for local tourists only.

Webnya tidak global... karena tidak dalam dua bahasa. Rrr semestinya dalam dua bahasa supaya turis asing juga bisa membacanya. (AA-LOC, 2017)

The interview data shows that the website is not going global. Therefore, it cannot persuade more potential tourists. This is to say that the website is only for local tourists. However, the website still uses the persuasive discourse to allure potential tourist. The website employs the discourse to help visitors search for the destination. Makassar city offers different kinds of historical tourist attractions in tourism websites. The visual element is one of the strategies to persuade potential tourist, as shown in Figure 1.

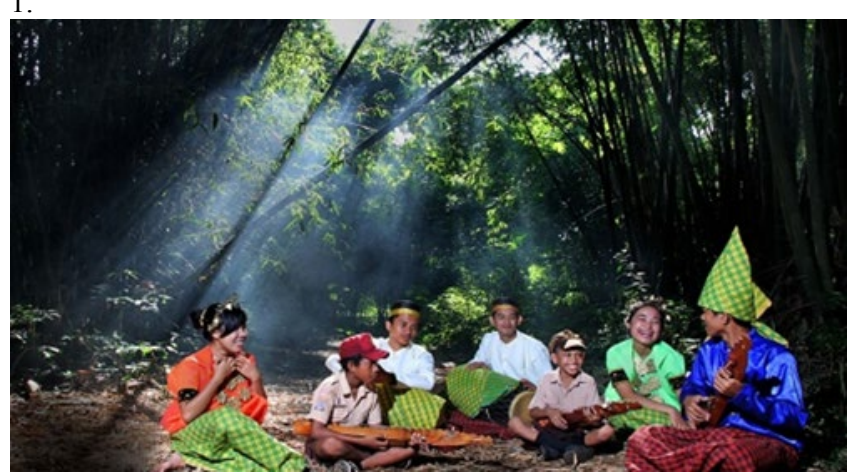

Fig. 1: Traditional attraction

The presence of a group of people with traditional costumes forms an image which focuses on people and place as an attractive model $[7,17]$. These people are as persuasive signifier because the combination between tradition and nature describes the positive image of the tourist attraction. Thus far, the findings show that the tourism website of Makassar depicts the persuasion element through the informative sentence and descriptive verbs. Former studies show that the tourists pursue the authenticity, genuineness, and uniqueness of the destinations $[13,62,16]$. Thus, the persuasive discourse has become the main discourse constructed in tourism the tourism website of Makassar. For example, the website portrays different cultural attractions - nature, city and traditional in a descriptive and informative way to allure the potential tourists.

In line with the tourism website of Makassar, the Tourism Office of Toraja is designed to promote the tourist attractions. The findings show that the discourse of persuasive is also dominant in portraying the tourist attractions. For example, Extract 2 employs specific syntactical choice to exaggerate the natural attractions on the website. 


\subsection{Extract 2}

"There is no better place in Toraja to experience the beauty of nature than Batutumonga. Located on a dramatic ridge, high on the slopes of Gunung (Mount) Sesean, 90 minutes' drive away from Rantepao, the capital of Toraja Utara. Batutumonga offers a relaxing ambiance, cool temperature, and beautiful views (TWT/D, 2017.

Extract 2 for example illustrates the use of particular terms.

"There is no better place in Toraja to experience the beauty of nature than Batutumonga and Batutumonga offers a relaxing ambiance, cool temperature, and beautiful views." The sentences meaningly engage the experience in Tana Toraja. Moreover, the words used such as relaxing, ambiance, calm and beautiful put across a strong sense of energy which allures the potential tourists as website viewers, in particular, frequent travelers.

The lexical choices are the dominant strategies and construct discourses in the text. Descriptive verbs are the dominant lexica choice used in TWT to influence the audience's image of the destination and affect her/his perception of the messages. The lexical choice also reflected in the tourist discourse gained from the interview conducted in this study.

Emm... well the tourist attraction in Toraja is very excited ...errr I like it very much. The website gives me a pre-info about the tourist attraction (SA-INT, 2017

Furthermore, modality and salience are employed in visual images to construct the discourse of persuasive. The "discourse of persuasive" strikingly portrays the tourist attraction. The local government provides information about tourist attraction that is related to the characteristic of Toraja. For example, the website presents the Tongkonan house in Figure 2 as the traditional house and natural attraction to potential tourist.

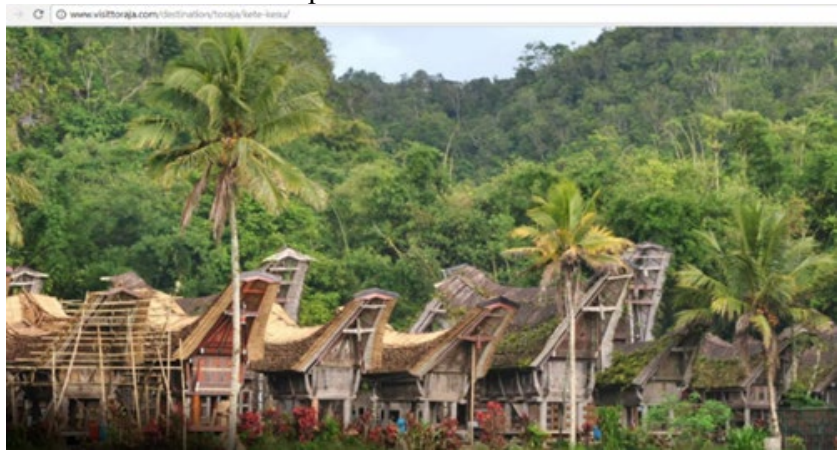

Fig. 2: Tongkonan Traditional House of Toraja

The findings illustrate that the lexical strategy and visual images used in TWT are mostly referred to as "persuasive". Regarding the textual element, the text illustrates the nature through lexical and syntactical strategies. Descriptive verbs are dominating strategies in constructing the discourse of persuasive. Furthermore, visual images are also an essential element in enhancing the tourist's view toward the destination image. The finding shows that modality and salience are two strategies used to support the textual element portraying the attraction. Visual image is the critical aspect in destination portrayal [6, 11, 63-67]. Thus, textual description and visual images on TWT illustrates the positive image of the tourist attractions to persuade the potential tourist. Discourses create knowledge about the destination image [58, 6870].

Syntactical and lexical choices, for instance, are the strategies used to identify the discourse of tourism constructed on the TWP. The specific word choice become the essential strategy in portraying the event. As one of the tourist destination for both domestic and international tourists, Parepare offers different attractions. For example, the TWP presents the important event to attract potential tourists (Extract 3 ). The persuasive element is the key words to describe the event of Parepare,

\subsection{Extract 3}

Festival Salo Karajae merupakan event rutin yang dilaksanakan pada tanggal 27 September setiap tahun di kawasan Salo Karajae. Pada event ini dipertunjukkan berbagai atraksi seni dan budaya tradisional yang melibatkan berbagai elemen masyarakat, berikut kegiatannya $(T W P / H, 2017)$

Linguistically, for example, the use of specific descriptive phrases "event rutin, attraksi budaya, and budaya traditional" to persuade potential tourist. Moreover, the extract also used the descriptive sentence "Pada event ini dipertunjukkan berbagai atraksi seni dan budaya traditional yang melibatkan berbagai element masyarakat, berikut kegiatannya" to explain the event which is offered by the Government on the TWP.

Text plays an important role to reveal the tourist destination and attractions. The TWP also constructs tourism via essential elements, which are i) cultural and ii) nature. The findings show descriptive verbs and declarative structures which illustrate the naturalness of Indonesia to lure potential tourists to enjoy the authentic tourist attractions of Parepare. However, there is a different description by the tourist which the interview revealed.

"sebernarnya ... websitenya tidak memberikan informasi yang lengkap. Rrr .. hanya menampilkan gambar tanpa ada penjelasan" (IIS LOC 2017).

The finding shows that the website has inadequate information about the tourist attraction in Parepare. The website should be rich with information in order to persuade the potential tourists. Parepare, as one of the tourist hubs in South Sulawesi, has a lot of tourist attractions, i.e., beaches, river, culture, and shopping. However, all these attractions are not presented well on the website. The website only explains the location without the description of the tourist attractions.

Visual elements also significantly contribute to the construction of a persuasive discourse on the TWP. Two dominant strategies used to construct the persuasion strategy on TWP which are: i) modality, and ii) salience. [67, 17]. Thus, visual elements play an essential role to enrich the tourist's perception. For example, the website presents pictures of Tonrangeng festival with a clear blue sky (see Figure 3). This picture portrays a group of dancers with the traditional costume on a traditional boat, with the river and sky background.

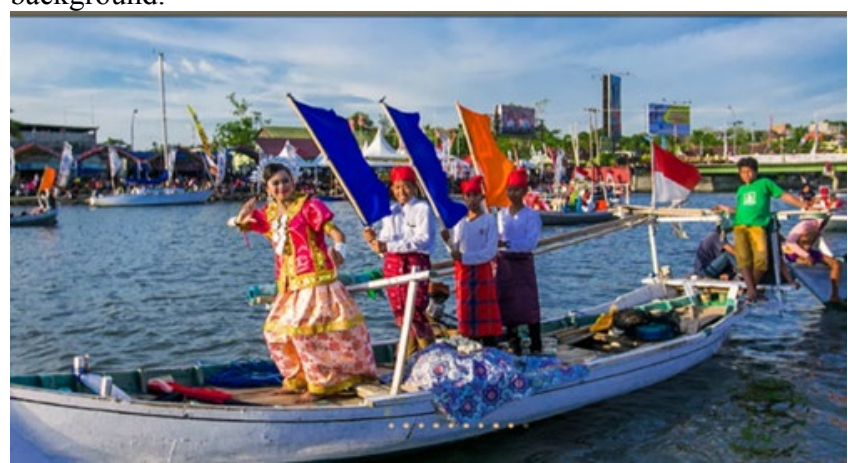

Fig. 3: Traditional Festival

The salient of the image signifies the excitement and authenticity of the traditional festival. Moreover, the utilization of color saturation constructs the naturalness, an authenticity of the destination.

The finding shows that TWP also employs the persuasive discourse to boost the destination image. The beautiful attractions of Parepare become a tourism asset. The discursive theme 
"persuasive" was mainly created to portray the untouched nature, tradition, and culture. At first glance, the finding shows that the language use and visual elements reveal persuasiveness [16, 17]. Tourism always involves the excitement of the novelty and originality of the tourist destinations or attractions [71]. In conclusion, the discourse of tourism constructed via text visual elements on the three tourism website: Tourism Website of Makassar, Tourism Website of Toraja and Tourism Website of Parepre. It clearly shows that the discourse of persuasive is the dominant discourse used to portray the destination.

Table 1: Discourse of tourism construction on the Tourism Website

\begin{tabular}{|c|c|c|c|}
\hline Discourse & $\begin{array}{c}\text { Tourism } \\
\text { Elements }\end{array}$ & Text Strategy & $\begin{array}{c}\text { Visual } \\
\text { Strategy }\end{array}$ \\
\hline \multirow[b]{3}{*}{$\begin{array}{c}\text { Discourse of } \\
\text { Persuasive }\end{array}$} & $\begin{array}{l}\text { cultural } \\
\text { heritage }\end{array}$ & $\begin{array}{c}\text { Lexical choice: } \\
\text { Descriptive verbs }\end{array}$ & Modality \\
\hline & Nature & $\begin{array}{c}\text { Lexical choice: } \\
\text { descriptive verbs } \\
\text { Syntactical choice: } \\
\text { descriptive sentences }\end{array}$ & $\begin{array}{c}\text { Salience } \\
\text { Participants }\end{array}$ \\
\hline & $\begin{array}{c}\text { Play: } \\
\text { Monument }\end{array}$ & $\begin{array}{c}\text { Lexical choice: } \\
\text { words, possessive } \\
\text { nouns } \\
\text { Syntactical choice: } \\
\text { declarative sentences } \\
\text { descriptive }\end{array}$ & $\begin{array}{l}\text { Modality } \\
\text { Salience }\end{array}$ \\
\hline
\end{tabular}

Overall, the tourism websites in South Sulawesi in particular TWM, TWT, and TWP are officially managed and controlled by each region in South Sulawesi to promote and market their tourism products and attractions. The website provides many links to portray destination image. This website highlights the tourism destinations via a big discursive theme persuasive. The tourism illustrates the persuasion strategy to portray the tourism attraction and product through language use and visual images. Thus, language use and visual images play a significant role to realize discourse of persuasive on the tourism website.

\section{Conclusion}

The main aspects of tourism promotion and marketing the destination on the website are language and visual elements. Language, for example, has become one of the aspects that persuade the potential or actual tourists and create schemata toward the destination $[16,72]$. The findings show that the tourism promotion of three regencies shapes the tourism destinations or attractions through discourse persuasive. Lexical and syntactical choices regularly boost the tourist knowledge and perception and experiences of the tourist attractions. The use of specific lexis and syntactical preference emphasizes the realization of destination portrayal. The text only employs descriptive verb and informative form to enhance the attraction. Moreover, the text only provides information about the location of the attraction in the tourism brochure.

Furthermore, the research has also shown that the discourse of persuasive is constructed through visual aspects to portray the destination. Modality and salience of the images are the strategies that create the discourse of persuasive. The finding of the study corresponds with the findings of [17] who recognized the tourism discourse. Hence, the visual strategy illustrates new experience and facts of the destinations.

Therefore, the discourse of persuasive that has emerged from the data analysis illustrates individual differences of the three websites in portraying the tourism destination. The discourse of persuasive is consistently and dominantly constructed to portray the destinations and tourist attraction on each website. The "persuasive" theme is the dominant and vigorous discourse which appears in the text and visual elements to enhance the tourism products and attraction portrayal. The tourism website is different from other tourism promotional media in which text and visual images are significantly employed to shape the destination image. Both text and visual aspect play an essential role to construct the reader's perception and prior knowledge. Therefore, language and visual images are also particularly emphasized and selected to portray the positive aspect of the destination.

\section{Acknowledgement}

The authors would like to express many thanks to the Research Management, Innovation and Commercialization Centre, Universiti Sultan Zainal Abidin, Terengganu, Malaysia for providing the financial assistance to support the publication fee of this article.

\section{References}

[1] World Travel and Tourism Council Economic Impact Singapore. http://www.wttc.org/research/economic-impact-research/countryreports/s/singapore/.

[2] Salim, M.A.M. Discourses of tourism in the official tourism website in Southeast Asia. PhD thesis. Universiti Teknologi Malaysia. (2015)

[3] Jørgensen, L.G. 'Uniquely Singapore': An analysis of a destination's image and the language of tourism. Thesis. Aarhus School of Business. (2004).

[4] Adams, K.M. The genesis of touristic imagery politics and poetics in the creation of a remote Indonesian island destination. Tourist Studies. 4(2), (2004): 115-135.

[5] Morgan N. \& Arnette P. Tourism promotion and power creating image: Creating identities. John Wiley and Sons. (1998).

[6] Salim, M.A.M. Enhancing des tination image on tourism brochure of Barru Regency Sulawesi Selatan, Indonesia: A tourism discourse perspective. Turizam (Tourism): Medunarrodni Znanstvenostrucni Casopis. 65(2), (2017): 247-257.

[7] Salim, M.A.B., Ibrahim, N.A. \& Hassan, H. Language for tourism: A review of literature. Procedia-Social and Behavioral Sciences. 62, (2012): 136-143

[8] Salim, M.A.M., Ibrahim, N.A. \& Hassan, H. Promoting diversity via linguistic and visual resources: An analysis of the Malaysian tourism website. LSP International. 1, (2014): 1-14.

[9] Salim, M.A.M, Ibrahim, N.A. \& Hassan, H. Authenticating the tourist destination on the official tourism website of Indonesia: A multimodal perspective. Astra Salvensis. 6(1), (2018): 333-343.

[10] Lawa, R., Qi, S. \& Buhalis, D. Progress in tourism management: A review of website evaluation in tourism research. Tourism Management. 31, (2010): 297-313.

[11] Loda, M.D. Comparing websites: An experiment in online tourism marketing. International Journal of Business and Social Science. 2(22), (2011): 70-78.

[12] Wan, C.S. The websites of international tourist hotels and tour wholesalers in Taiwan. Tourism Management. 23(2), (2002): 155160 .

[13] Boyne, S., Hall, D. \& Williams, F. Policy, support and promotion for food related tourism initiatives: A marketing approach to regional development. Journal of Travel and Tourism Marketing. 14(3/4), (2003): 131-154.

[14] du Rand, G. E., Heath, E. \& Alberts, N. The role of local and regional food in destination marketing: A South African situation analysis. Journal of Travel and Tourism Marketing. 14(3/4), (2003): 97-112.

[15] Horng, J.S. \& Tsai, C.T. Government websites for promoting East Asian culinary tourism: A cross-national analysis. Tourism Management. 31, (2010): 74-85.

[16] Dann, G.M.S. The language of tourism: A sociolinguistic perspective. CAB International. (1996).

[17] Kress, G. \& Van Leeuwen, T. Reading images the grammar of visual design. Routledge. (2006).

[18] Hallett, R. W. \& Weinger, J.K. Official tourism websites: A discourse analytic perspective. St. Nicolas House: Channel View Publication. (2010).

[19] Triandjojo, I. Semiotika iklan mobil di media cetak Indonesia. Master thesis. Universitas Diponegoro Semarang. (2008).

[20] McIntosh, R.W., Goeldner, C.R. \& Ritchie, J.R.B. Tourism principles, practices, philosophies. John Wiley and Sons. (1995)

[21] Palmer, C. Tourism and the symbols of identity. Tourism Management. 20, (1999): 313-321. 
[22] Dregde, D. \& Jenkins, J. Tourism planning and policy. John Wiley and Sons. (2007).

[23] Reisinger, Y. International tourism: Culture and behavior. Butterworth-Heinemann. (2009).

[24] Urry, J. The 'consuming' of place. In A. Jaworski \& A. Pritchard (Eds.), Discourse, Communication and Tourism. Clevedon: Channel View Publication. (2010). pp. 19-27.

[25] Dann, G.M.S. Remodelling a changing language of tourism: From monologue to dialogue and trialogue. Pasos, Revista de Turismo y Patrimonio Culture. 10(4), (2012): 56-70.

[26] Jo'hannesson, G.T. \& Huijbens, E.H. Tourism in times of crisis Exploring the discourse of tourism development in Iceland. Current Issues in Tourism. 13(5), (2010): 419-434.

[27] Razusova, M. The language of tourism. (2009) http://www.pulib.sk/web/kniznica/elpub/dokument/ferencik2/subor/ 27.pdf.

[28] Midalia, S. Textualising gender. Interpretations. 32(1), (1999): $27-$ 32.

[29] Pan, S., Henry, T. \& Jinson, L. Framing New Zealand: Understanding tourism TV commercials. Tourism Management, 32, (2011): 596-603

[30] Hvass, K.A. \& Ana, M.M. The takeoff of social media in tourism. Journal of Vacation Marketing. 18, (2012): 93-103.

[31] Grimm, K.E. \& Needham, M.D. Internet promotional material and conservation volunteer tourist motivations: A case study of selecting organizations and projects. Tourism Management Perspectives. 1, (2012): 17-27.

[32] Cousins, J.A., Evans, J. \& Saddler, J. Selling conservation? Scientific legitimacy and the commodification of conservation tourism. Ecology and Society. 14(1), (2009): 1-18.

[33] Jaworski, A. \& Thurlow, C. Language and the globalizing habitus of tourism: A sociolinguistics of fleeting relationships. In $\mathrm{N}$. Coupland (Ed.), The Handbook of Language and Globalization. West Sussex: Blackwell Publishing. (2010). pp. 255-286.

[34] Najafian, M. Advertising social semiotic representation: A critica approach. International Journal of Industrial Marketing. 1(1) (2011): 63-78

[35] MacChannel, D. The tourist: New theory of leisure class. University of California Press. (1976).

[36] Mocini, R. The verbal discourse of tourist brochure. Annals. 5, (2005): 153-164.

[37] Urry, J. The tourist Gaze. Sage Publications. (2002).

[38] Boyer, M. \& Viallon, P. La communication touristique. Presses Universitaires de France. (1994).

[39] Santosa, C.A., Belhassenb, Y. \& Catona, K. Reimagining Chinatown: An analysis of tourism discourse. Tourism Management. 29, (2008): 1002-1012.

[40] Zhang, Y. Book review: Richard W. Hallett and Judith KaplanWeinger Websites: A discourse analysis perspective. Discourse and Communication. 5(4), (2011): 434-436.

[41] Thurlow, C. \& Jaworski, A. Tourism discourse language and global mobility. Palgrave Macmilan. (2010).

[42] Jaworski, A. Linguistic landscapes on postcards: Tourist mediation and the sociolinguistic communities of contact. Sociolinguistics Studies. 4(3), (2010): 569-594

[43] Fakharyan, M., Jalilv, M.R., Elyasi, M. \& Mohammadi, M. The influence of online word of mouth communications on tourists' attitudes toward Islamic destinations and travel intention: Evidence from Iran. African Journal of Business Management. 6(33), (2012): 9533-9542.

[44] Suradnya, I.M. Pengembangan kurikulum pendidikan tingg kepariwisataan sesuai dengan tuntutan wisatawan. Jurnal Pendidikan dan Pengajaran IKIP Negeri Singaraja. 39(4), (2006): 906-926.

[45] Hassan, H. Social semiotics: Realizing destination image by means of cultural representations. International Journal of Social Science and Humanity. 5(1), (2015): 149-153.

[46] Molina, A., Gómez, M. \& Martín-Consuegra, D. Tourism marketing inormation and destination image management. African Journal of Business Management. 4(5), (2010): 722-728.

[47] Tasci, A., \& Gartner, W. Destination image and its functional relationships. Journal of Travel Research. 45, (2007): 413-425.

[48] Hassan H., Habil, H. \& Nazir, M.Z. Persuasive strategies of tourism discourse. In H. Habil \& H. Hassan (Eds.), New Perspectives in Language and Communication Research. Johor: UTM Press. (2010): pp. 1-9.

[49] Pan, S., Ting, P.H. \& Bau, D.Y. Perceptions of Taipei as revealed in travel blogs: A tale from two sides. Asia Pacific Journal of Tourism Research. 19(6), (2014): 700-720.
[50] Law, R. Internet and tourism - Part XXII: Chinatravel.net. Asia Pacific Journal of Tourism Research. 15(4), (2010): 461-463.

[51] Kim, D.Y., Hwang, Y.H. \& Fesenmaier, D. R. Modeling tourism advertising effectiveness. Journal of Travel Research. 44, (2005): 42-49.

[52] Kasli, M. \& Avcikurt, C. An investigation to evaluate the websites of tourism departments of universities in Turkey. Journal of Hospitality, Leisure, Sport and Tourism Education. 7(2), (2008): 77-93.

[53] Lepp, A., Gibson, H. \& Lane, C. Image and perceived risk: A study of Uganda and its official tourism website. Tourism Management. 32, (2011): 675-684

[54] Buhalis, D. \& Law, R. Progress in information technology and tourism management: 20 years on and 10 years after the internet: The state of e-tourism research. Tourism Management. 29(4), (2008): 609-623.

[55] Fürsich, E. \& Robins M.B. Visiting Africa: Constructions of nation and identity on travel websites. Journal of Asian and African Studies. 39(1-2), (2004): 133-152.

[56] Muylle, S., Moenaert, R. \& Despontin, M. The conceptualization and empirical validation of website user satisfaction. Information and Management. 41, (2004): 543-560.

[57] Barnes, S.J. \& Vidgen, R. Interactive e-government: Evaluating the website of the UK inland revenue. International Journal of Electronic Government Research. 3(1), (2007): 19-38.

[58] Berger, P.L. \& Luckmann, T. The social construction of reality: A treatise in the sociology of knowledge. Penguin Books. (1966).

[59] Tuchman, G. Media institutions qualitative methods in the study of news. In K. B. Jensen \& N. W. Jankowski (Eds.), A Handbook of Qualitative Methodologies for Mass Communication Research. London: Routledge. (2002): pp. 93-106.

[60] Snepenger, D., Snepenger, M., Dalbey, M. \& Wessol, A. Meanings and consumption characteristics of places at a tourism destination. Journal of Travel Research. 45, (2007): 310-321.

[61] Saraniemi, S. \& Kylänen, M. Problematizing the concept of tourism destination: An analysis of different theoretical approaches. Journal of Travel Research. 50(2), (2011): 133-143.

[62] Feighery, W. Reading tourism texts in context: A critical discourse analysis. Tourism Analysis. 11, (2006): 1-11.

[63] Choi, S., Xinvan, Y.L. \& Alastair, M.M. Destination image representation on the web: Content analysis of Macau travel related websites. Tourism Management. 28, (2007): 118-129.

[64] Gotti, M. The language of tourism as specialized discourse. In O. Palusci \& S. Francesconi (Eds.), Translating Tourism: Linguistic/Cultural Representations. Trento: Editrice Università Degli Studi di Trento. (2006): pp. 15-34.

[65] Nigro, M.G. Il linguaggio specialistico del turismo: Aspetti storici, teorici e traduttivi. Aracne Editrice. (2006).

[66] Francesconi, S. English for tourism promotion: Italy in British tourism texts. Hoepli. (2007)

[67] Hodge, R. \& Kress, G. Social semiotics. Cornell University Press. (1988).

[68] Stamou, A.G. \& Paraskevopoulos, S. Images of nature by tourism and environmentalist discourses in visitors books: A critical discourse analysis of ecotourism. Discourse and Society. 15(1), (2004): 105-129.

[69] Hassan, H. Multimodal communication of corporate website design. Universiti Teknologi Malaysia Press. (2012).

[70] Huisman, S. \& Moore, K. Natural language and that of tourism. Annals of Tourism Research. 26(2), (1999): 445-449.

[71] Cohen, E. The study of touristic images of native people: Mitigating the stereotype of a stereotype. in D.G. Pearce \& R.W. Butler (Eds.), Tourisni Reseurcli: Critiques and cliallenges. London: Routledge. (1993). pp. 36-69.

[72] Zhang, Y. Book review: Richard W. Hallett and Judith KaplanWeinger, Websites: A discourse analysis perspective. Discourse and Communication. 5(4), (2011): 434-436 